\title{
Skeletal remains with otoliths in situ of the Miocene croaker Trewasciaena cf. kokeni (Teleostei, Sciaenidae) from the Pannonian of the Vienna Basin
}

\author{
Tomáš PřıKryl, Rostislav Brzobohatý \& Giorgio Carnevale
}

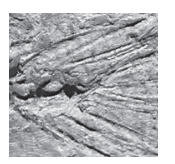

\begin{abstract}
Two articulated skeletons of juvenile sciaenids referred to Trewasciaena cf. kokeni based on their saccular otoliths preserved in situ are described herein. The specimens provide the only available skeletal evidence of the genus Trewasciaena in the record and are characterized by moderately cavernous frontals, poorly developed supraoccipital crest, premaxilla bearing a large articular process with rounded dorsal margin, dentary and anguloarticular firmly articulated, lower jaw joint located in level of anterior half of orbit, jaw teeth small and probably arranged in single row, preopercle crescent shaped with small and regularly spaced spines along the posterior border of its vertical arm, vertebral column apparently containing 24 vertebrae, seven pairs of ribs, caudal skeleton with five autogenous hypurals, slender parhypural, two uroneurals and three epurals, haemal spines of the second and third preural vertebrae autogenous, neural spine of second preural vertebra reduced, elongated dorsal fin with ten or eleven spines and 23 soft rays, short-based anal fin with two spines and probably four soft rays, second anal spine much longer than the first one, pectoral fin probably composed of eight short rays, body densely covered by scales. Despite the potential relevance of these specimens for our understanding of the relationships of Trewasciaena within the Sciaenidae, the concurrent effect of their incompleteness, inadequate preservation and juvenile nature prevented any conclusive statement about the phylogenetic position of this extinct genus, which remains elusive. - Key words: Sciaenidae, Pannonian, Miocene, articulated skeleton, otoliths in situ, Vienna Basin.
\end{abstract}

Přikryl, T., Brzobohatý, R. \& Carnevale, G. 2021. Skeletal remains with otoliths in situ of the Miocene croaker Trewasciaena cf. kokeni (Teleostei, Sciaenidae) from the Pannonian of the Vienna Basin. Bulletin of Geosciences 96(1), 19-28 (7 figures). Czech Geological Survey, Prague. ISSN 1214-1119. Manuscript received August 13, 2020; accepted in revised form November 2, 2020; published online November 16, 2020; issued January 10, 2021.

Tomáš Přkryl, Institute of Geology of the Czech Academy of Sciences, Rozvojová 269, CZ-16500 Praha 6, Czech Republic; prikryl@gli.cas.cz • RostislavBrzobohatý, Department of Geological Sciences, Masaryk University, Kotlár̆ská 2, CZ-611 37 Brno, Czech Republic • Giorgio Carnevale, Dipartimento di Scienze della Terra, Università degli Studi di Torino, Via Valperga Caluso, 35, I-10125 Torino, Italia

The Sciaenidae is a speciose family of percomorph fishes that comprises more than 280 extant species arranged in 67 genera, which inhabit marine, brackish and freshwater environments worldwide (Nelson et al. 2016). These fishes are known for their ability to vocalize, for which they are commonly named drums or croakers (see, e.g. Sasaki 1989, Ramcharitar et al. 2006). The fossil record of this group is primarily represented by the otoliths that are especially common and abundant in Neogene clastic deposits (see, e.g. Schwarzhans 1993, Nolf 2013). Sciaenid otoliths are taxonomically informative because of their large size and species-specific morphology, being commonly used also to separate the extant members of the family. Conversely, fossil articulated skeletal remains are relatively rare (see Bannikov et al. 2009, 2018; Bannikov 2010; Otero et al. 2013) and their systematic interpretation is complicated by the fact that the classification of the extant members of this family is primarily based on soft anatomical features, including pores on snout and lower jaw, barbels, lateral-line morphology, cavernous canals on the head, and morphology of the swimbladder (see Trewavas 1962, 1964, 1977; Chao 1978, 1986, 2002, 2016; Sasaki 1989; Walker \& Radford 1992; Nelson et al. 2016). In this context, an unique opportunity to properly interpret the affinities of fossil sciaenids is represented by skeletal remains with otoliths preserved in situ (see, e.g. Schwarzhans \& Carnevale 2017, Schwarzhans et al. 2018), as recently demonstrated by Bannikov et al. (2018) based on Paratethyan material.

Here we describe two sciaenid articulated skeletons with otoliths in situ from the Pannonian of the Vienna Basin. The otoliths in situ suggest that the fossils pertain to the extinct genus Trewasciaena, thereby providing the first known record of skeletal remains of this genus. 


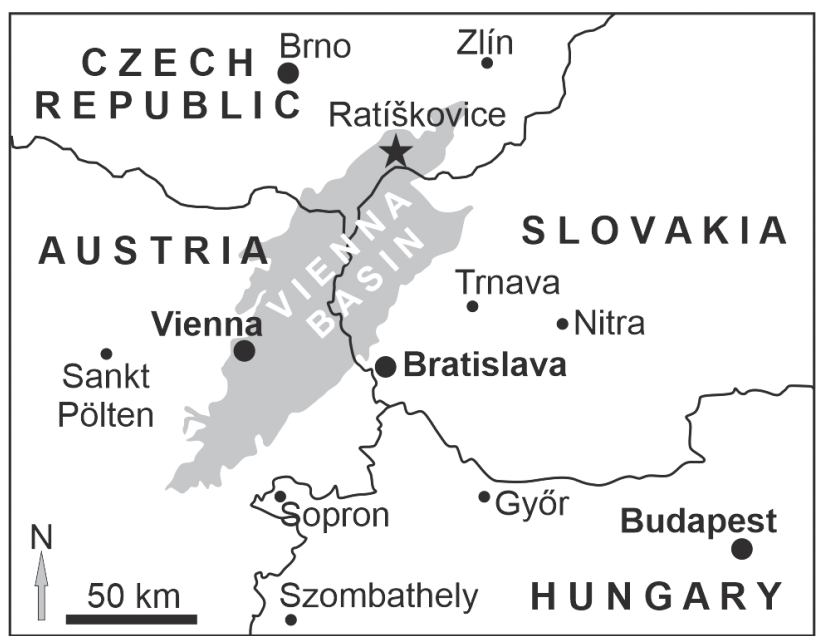

Figure 1. Sketch map of the Vienna Basin showing the position of the Ratíškovice village. Modified from Kováč et al. (2008).

The main goal of this paper is therefore to provide a descriptive analysis of these fossils and discuss their possible affinities within the Sciaenidae.

\section{Geological note}

The fossils described herein were collected from the organic rich laminated argillites overlying the Dubňany Seam (Dubňany or Ratíškovice; Fig. 1) in one of the Dubňany lignite mines located in the South Moravian lignite district, Vienna Basin.

The Dubňany lignite seam developed within Pannonian sediments representing the younger of the two main lignitiferous layers in the area (Čtyroký 2000, Honěk et al. 2010). It is lying at the base of the lowermost "cyclotheme" ("F1" level; Jiříček 1985) of the Dubňany Formation (Čtyroký 2000). Although we are unable to definitely confirm the origin of the fossils described herein (see below), Honěk et al. (2010) mentioned the presence of abundant fish remains in the argillites of the second overlying level of impermeable rock developed within Dubňany Fm. (“Zone F”, according to Papp 1951). These deposits originated along the northern margins of the Vienna Basin in a sedimentary context dominated by argillites and clays alternated with sandy layers (Honěk et al. 2010).

The general regressive trend and the regional transition to brackish and/or freshwater environments during the Pannonian (Harzhauser et al. 2004, Honěk et al. 2010) suggest that brackish or freshwaters occurred in the original palaeobiotope. The analysis of pollens and dinoflagellates from the "Zone F" are indicative of floodplain and swampy vegetation (with occasional higher salinity) within an open and possibly weakly vegetated landscape (Doláková \& Kováčová 2008, Honěk et al. 2010).

\section{Material and methods}

According to original documents associated with the argillitic slabs, it seems that they were collected in 1958 in the "Mine C" (= former name of the Mine Osvobození) within the "overburden of Dubňany seam". On the other hand, the information written directly on the slab of rock indicates the locality "GV1" and depth $106 \mathrm{~m}$. According to Knobloch (1969), fossil material from "Dubňany" may derive from three different sites, mines "1. máj", "Osvobození" and ventilation shaft "GV1", although the material from the first two sites was collected in the mine dumps.

The argillitic slabs that include two fish specimens with otoliths preserved in situ (as a part and counterpart; Fig. 2) are housed in the Paleontological Department of the National Museum in Prague with the numbers NMP Pv11673 and NMP Pv11674. The sagitta removed from one of the fossils was recognized as belonging to a juvenile individual referred to as Trewasciaena cf. kokeni (Schubert, 1902) by R.B. and used as a primary taxonomic indicator.

The specimens were examined using a Leica Stereomicroscope Leica MZ6 equipped with a camera lucida drawing arm. The photos were prepared using a Canon EOS 1000D associated with the stereomicroscope.

Anatomical abbreviations: aa - anguloarticular; br branchiostegal rays; bsph - basisphenoid; $\mathrm{CaL}$ - cauda lenght; cv - caudal vertebra; d - dentary; epu - epural; $\mathrm{fr}$ - frontal; hm - hyomandibula; hspu - haemal spine of the preural vertebra; hyp - hypural; $\mathrm{mx}$ - maxilla; $\mathrm{OH}$ otolith height; OL - otolith length; op - opercle; OsH ostium height; OsL - ostium length; pg - pterygiophore; php - parhypural; pmx - premaxilla; pop - preopercle; psph - parasphenoid; ptsph - pterosphenoid; pu - preural vertebra; q - quadrate; ra - retroarticular; ry - fin ray; sg sagitta; SL - standard length; soc - supraoccipital; sp - fin spine; sy - symplectic; TL - total length; un - uroneural.

\section{Systematic part}

Family Sciaenidae Cuvier, 1829

Genus Trewasciaena Schwarzhans, 1993

Trewasciaena cf. kokeni (Schubert, 1902)

Figures 2-7

? 1902 Otolithus (Sciaenidarum) Kokeni; Schubert, pl. 10, fig. 18.

? 2013 Trewasciaena kokeni (Schubert, 1902). - Schultz, p. 328, pl. 91, figs 1-5. (cum syn., non fig. 3a, b).

? 2018 Trewasciaena kokeni (Schubert, 1902). - Bannikov et al., fig. $8 \mathrm{f}-\mathrm{j}$. 

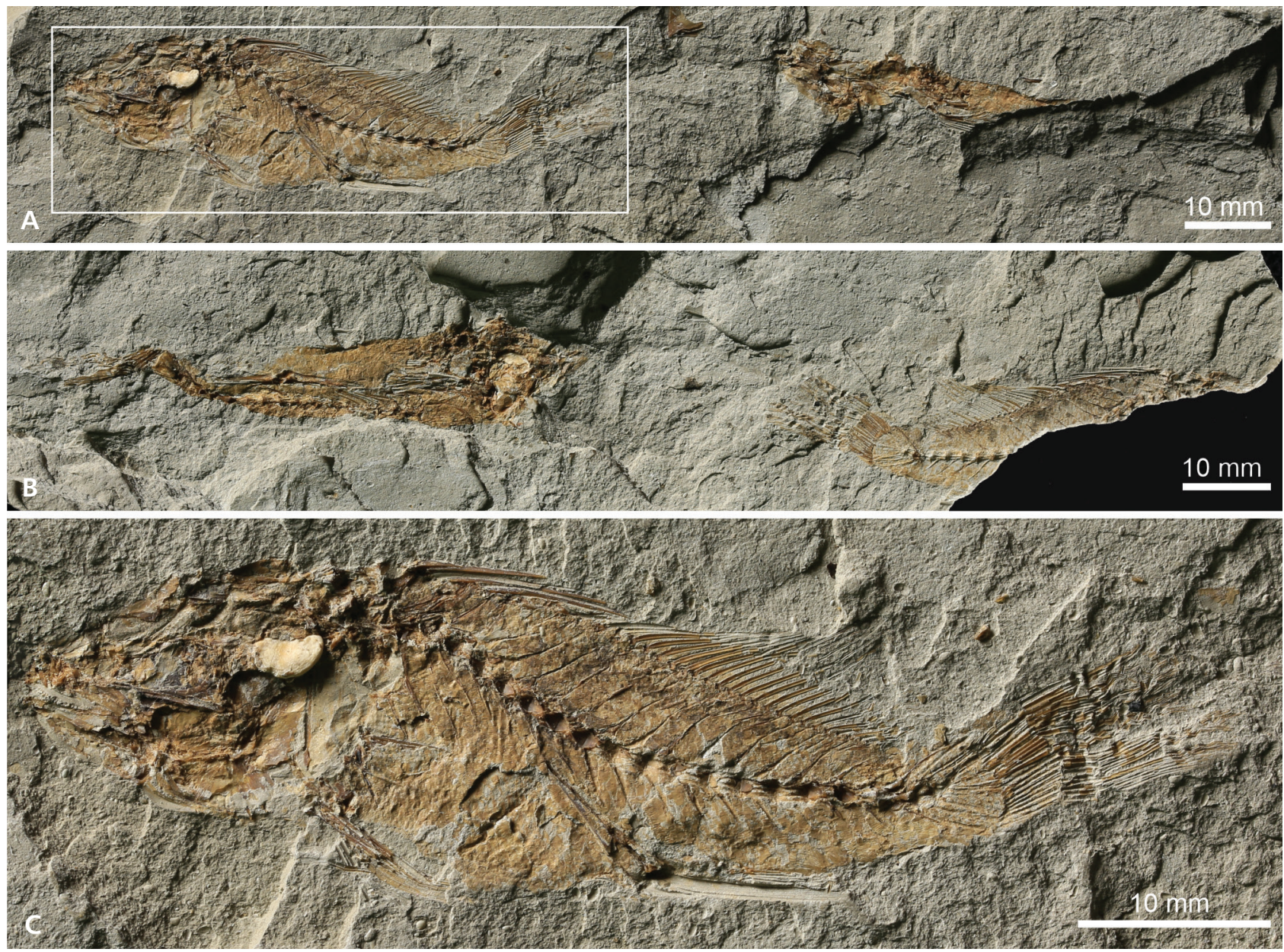

Figure 2. Articulated skeletons of Trewasciaena cf. kokeni (Schubert, 1902) with otoliths in situ; A - slab including NMP Pv11674a (left) and NMP Pv11673b (right); B - counterpart of the slab in A, including NMP Pv11673a (left) and NMP Pv11674b (right); C - NMP Pv11674a, left lateral view.
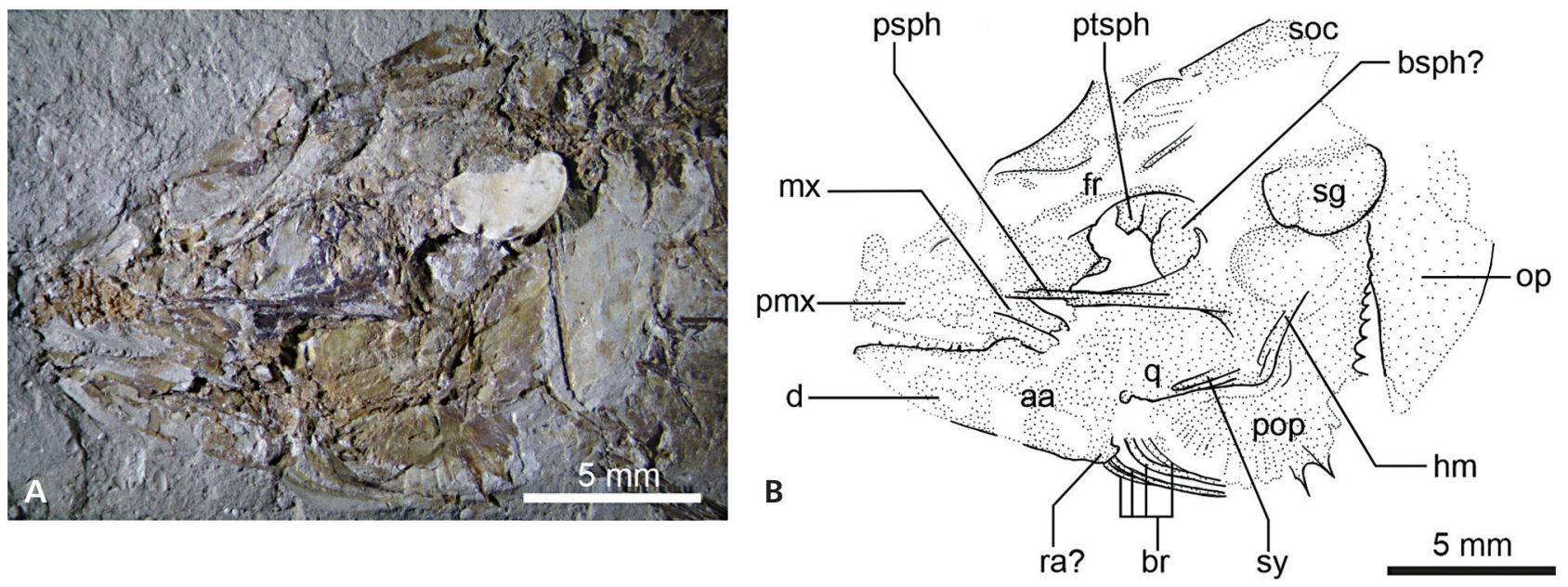

Figure 3. Trewasciaena cf. kokeni (Schubert, 1902); A - head of NMP Pv11674a, left lateral view; B - interpretative drawing.

For full synonymy and cited occurrences of the T. kokeni see Schultz (2013). Other synonyms are: Otolithus (Sciaenidarum) cfr. loczyi - Lörenthey (1906, pl. 3, fig. 24, non fig. 23), Umbrina sp. - Carnevale et al. (2006, fig. 3b), Trewasciaena kokeni (Schubert, 1902) - Bannikov et al. (2018, fig. 8f-j). Some other tentative synonymy data are: Trewasciaena kokeni (Schubert, 1902) - Bosnakoff (2008, pl. 3, figs 1-8); "genus aff. Umbrina" kokeni (Schubert, 1902) - Bosnakoff (2011, fig. 5o); 

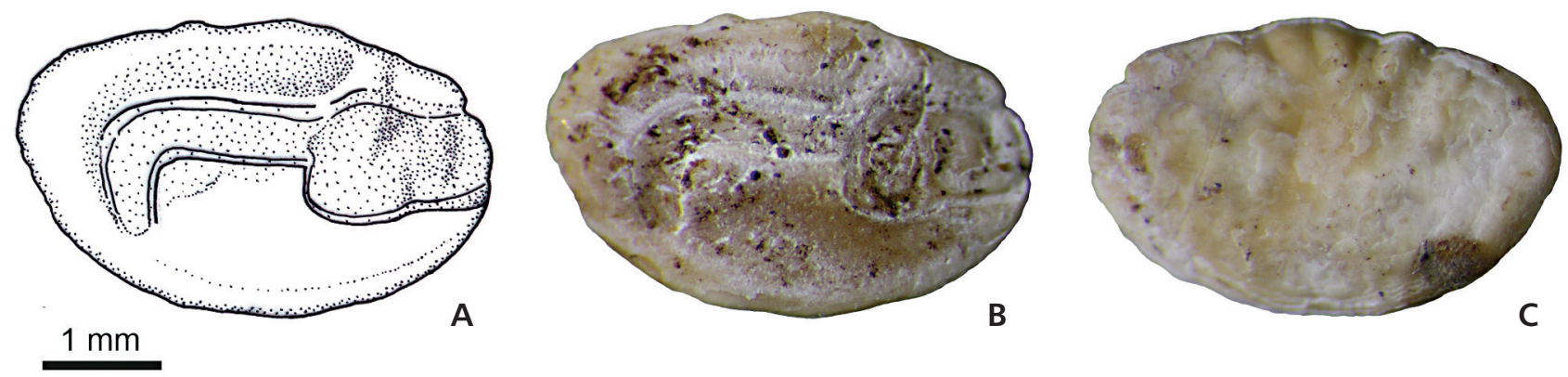

Figure 4. Trewasciaena cf. kokeni (Schubert, 1902). Left sagitta of NMP Pv11673c; A - interpretative drawing (inner face); B - inner face; $\mathrm{C}$ - outer face.
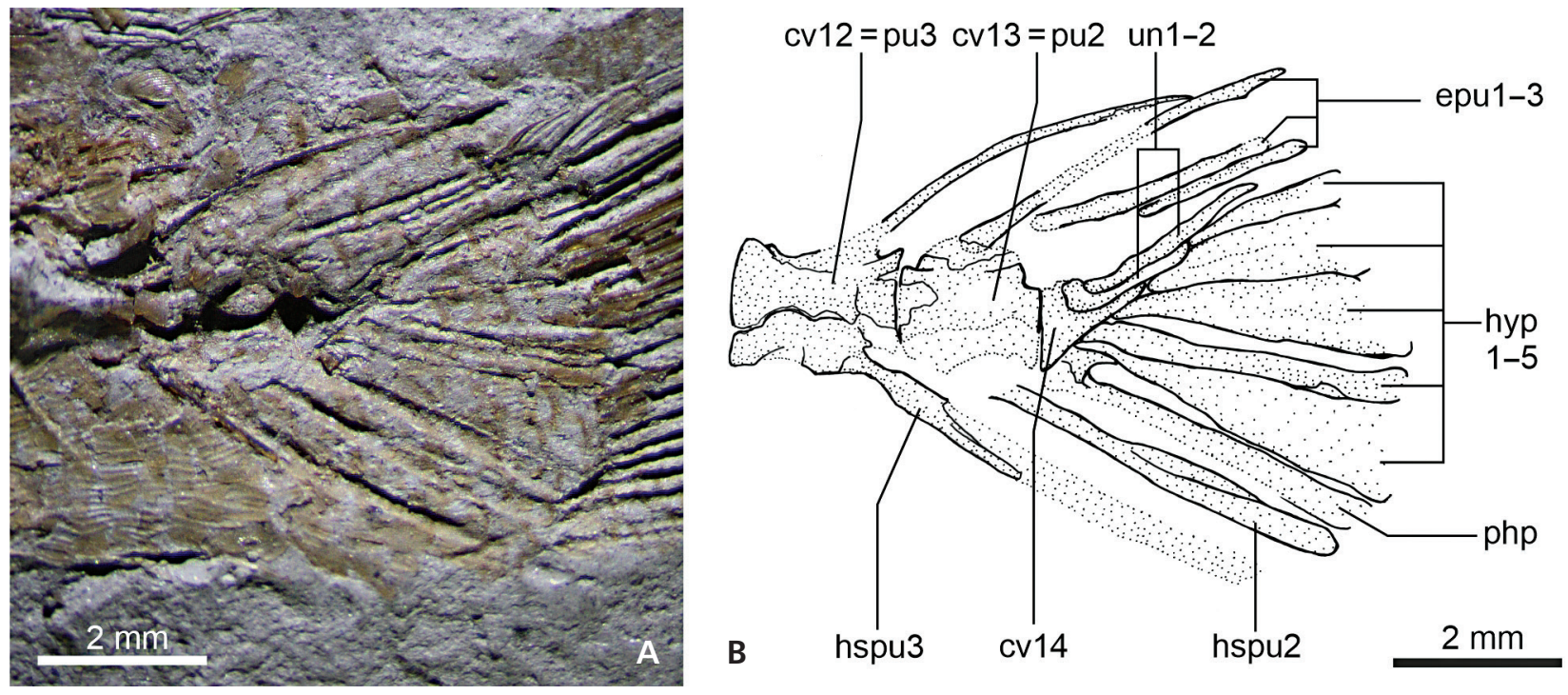

Figure 5. Trewasciaena cf. kokeni (Schubert, 1902); A - caudal skeleton of NMP Pv11674a; B - interpretative drawing.

"Trewasciaena" sp. - Colombero et al. (2017, fig. 5.14), and "Trewasciaena" sp. - Carnevale et al. (2018, fig. 3r).

Material. - NMP Pv11673, a partially complete and poorly preserved articulated skeleton with otolith in situ. Specimen NMP Pv11674, a partially complete, moderately preserved, articulated skeleton with otolith in situ, in part and counterpart; $\mathrm{SL}=50.9 \mathrm{~mm}, \mathrm{TL}=63.8 \mathrm{~mm}$.

Description. - Measurements (in \% of SL; based on NMP Pv11674): head length $=35.6$; head depth $=25.9$; caudal fin length $=25.3$; caudal peduncle length $=8.5$; predorsal length $=37.5$; preanal length $=60.1$; prepelvic length $=$ 31.63; dorsal-fin base length $=51.1$; anal-fin base length $=$ 11.4; length of first anal-fin spine $=5.1$.

Otolith measurements (in mm; Fig. 4): otolith length $(\mathrm{OL})=3.9$; otolith height $(\mathrm{OH})=2.4 ; \mathrm{OL} / \mathrm{OH}=1.6 ; \mathrm{CaL} /$ $\mathrm{OsL}=1.1 ; \mathrm{OsL} / \mathrm{OsH}=1.34$.

The body is moderately elongate and the head is almost triangular in lateral view. The dorsal profile of the body is convex while the ventral profile is almost straight.

The head (Fig. 3) is poorly preserved in both available specimens, with bones extensively crushed and difficult to distinguish from each other. The frontals appear to be moderately cavernous dorsally and bear a ventral interorbital laminar extension. The supraoccipital crest is poorly developed. In the posterior wall of the orbit the pterosphenoid and what appears to be the basisphenoid are recognizable in NMP Pv11674. The parasphenoid is stout, and almost straight.

The mouth is terminal, with a gape extending posteriorly up to the anterior margin of the orbit. The premaxilla seems to possess a large articular process with a rounded dorsal margin. The maxilla is poorly preserved. The mandible is thick with firmly articulated dentary and anguloarticular, which form a moderately developed coronoid process originating at the end of the dentary tooth row. The lower jaw joint is located in the level of the anterior half of the orbit. A tiny quadrangular retroarticular is recognizable at the posteroventral corner of the 

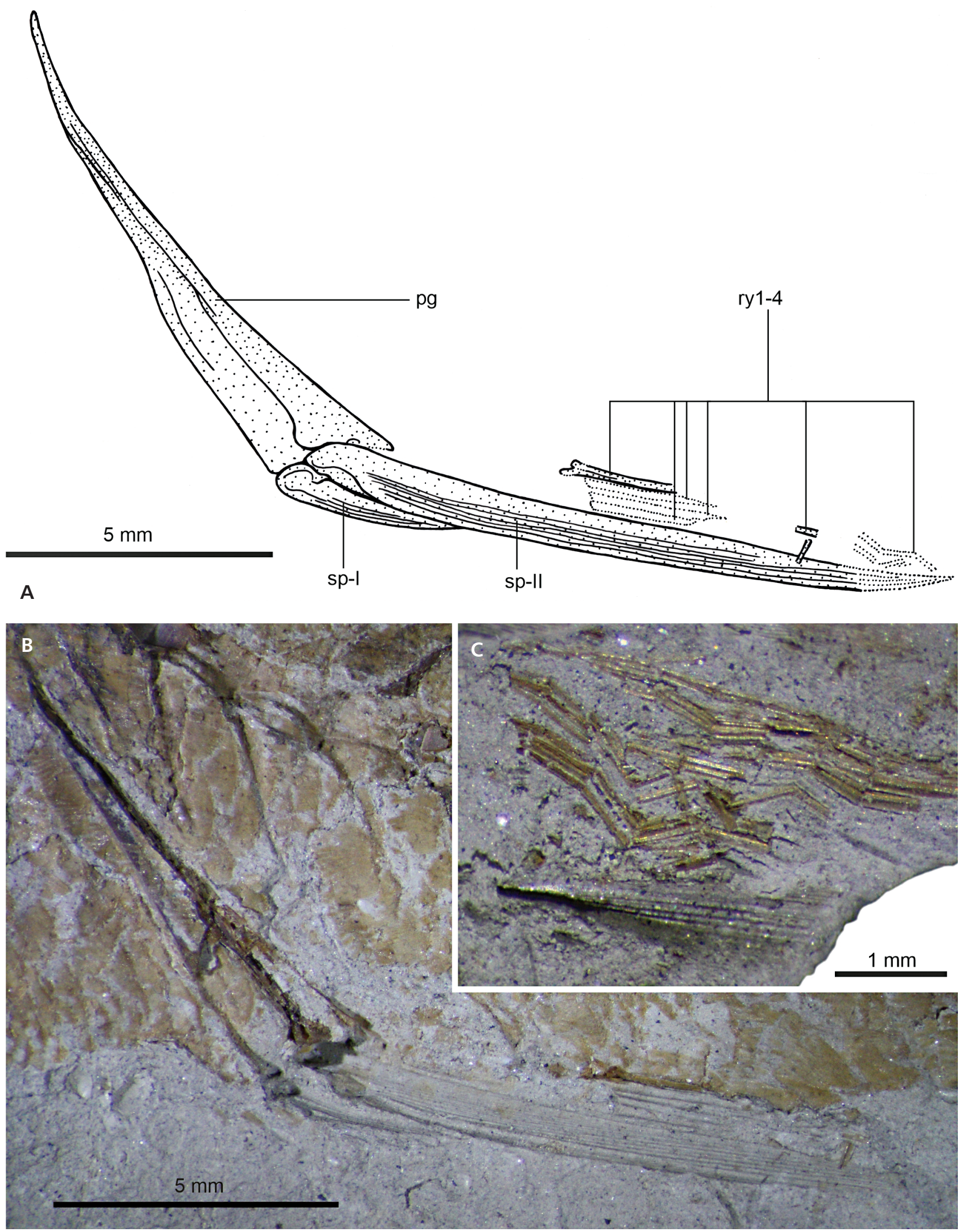

Figure 6. Trewasciaena $\mathrm{cf}$. kokeni (Schubert, 1902). Anterior part of the anal fin of NMP Pv11674; A - interpretative drawing (based on part and counterpart); B - NMP Pv11674a, left lateral view; C - anal-fin rays of NMP Pv11674b, right lateral view. 
mandible. Both the upper and lower jaws bear small teeth probably arranged in a single row. The original number of teeth is difficult to determine. Of the supensorium only part of the quadrate, a posterodorsally expanded symplectic and the opercular process of the hyomandibula are preserved and recognizable in NMP Pv11674. The preopercle is crescent shaped and bears small and regularly spaced spines along the posterior border of its vertical arm; a couple of large spines are also present at the angle formed by the vertical and horizontal arms, although the original complement cannot be properly defined. The opercle is a laminar bone with a linear and vertical anterior margin. A robust hyoid bar is partially preserved together with an indeterminate number of poorly preserved branchiostegal rays.

The saccular otoliths (sagittae) are exposed in the otic region of the neurocranium (Figs 2-3) of both the specimens. The left sagitta has been extracted from the specimen NMP Pv11673. The overall morphology of the sagitta (Fig. 4) is indicative of the juvenile nature of the individuals. The outline is elliptic with concave ventral rim and approximately centrally laying deepest point $(\mathrm{OL} / \mathrm{OH}=1.58)$. The dorsal rim is weakly undulated in the middle part. The anterior rim is rounded with a weekly protruding ostial colliculum. The inner face is slightly convex, the outer face mildly concave and without umbo. It shows the typical sciaenid sulcus that is distinctly supramedian. The oval ostium narrows anteriorly and is clearly restricted in the middle and is also characterized by a clearly precaudal depression. The cauda is long, narrow, and deepened, with its rear part bent downward forming an angle of $90^{\circ}$ with the horizontal part, ending slightly below the lower level of the ostium. The horizontal section of the cauda is slightly longer than the ostium. A ventral furrow is weekly developed and runs parallel to the ventral rim. A well-developed, relatively high and deep dorsal depression is visible above the connection between the ostium and the cauda and follows almost the entire caudal length becoming gradually narrower. The space between the rear margin of the ostium and downturned portion of the cauda measures about $37 \%$ of the sulcus length, a typical feature of the genus Trewasciaena (see Bannikov et al. 2018).

The vertebral column is sigmoid and consists of approximately 24 vertebrae. Despite the anterior part of the vertebral column is not clearly preserved, the abdominal portion appears to contain around ten vertebrae, while the caudal portion consists of 14 vertebrae. There are seven pairs of ribs, the first of which articulates with what appears to be the third abdominal centrum. The caudal skeleton (Fig. 5) contains five autogenous hypurals, a slender parhypural, two uroneurals and three epurals. The haemal spines of the second and third preural vertebrae seem to be autogenous. The neural spine of the second preural vertebra is reduced to a low and almost rounded crest. Due to the inadequate preservation, it is not possible to determine whether the caudal fin is truncate or rounded. There are $17(9+8)$ elongate principal caudal-fin rays plus four dorsal and four ventral procurrent rays. The predorsal region is poorly preserved in both available specimens and, for this reason, there is no evidence of the original complement of supraneurals. The dorsal fin is notably elongated and contains ten or eleven spines followed by 23 soft rays. The fin is notched due to the shortening of the penultimate spine. The first dorsal-fin pterygiophore bears two supernumerary spines. The anal fin originates just below the fourth and fifth caudal vertebrae. It is relatively short based (slightly more than 10\% of SL) and consists of two longitudinally striated spines followed by at least four soft rays. The second spine is much longer and massive than the first one - the second spine is about four times longer than the first spine and about as long as the first soft ray (see Fig. 6). The first anal-fin pterygiophore is strongly inclined and massive. The paired fins and their girdles are scarcely preserved, although fragments of the pectoral fin suggest that it was composed of at least eight rather short rays. The pelvic fins are partially preserved in the specimen NMP Pv11673; they insert slightly anteriorly to the pectoral fins and consist of a single pointed spine and five rays. The distal extremities of the pelvic-fin rays extend backward to the level of the penultimate abdominal vertebra.

The body is densely covered by scales. The head and the proximal part of the caudal fin are covered by small cycloid scales, while the rest of the body is covered with ctenoid scales. Ctenoid scales show a few rows of short ctenii, and well-developed radii, which are present in numbers of seven to nine. The lateral line is not clearly recognizable.

\section{Discussion}

Considered to be closely related to the Haemulidae (Trewavas 1977, Schwarzhans 1993), the family Sciaenidae is currently aligned with the Polynemidae based on the shared possession of a suite of muscular and skeletal features (Johnson 1993, Presti et al. 2020). Sciaenids can be easily defined based on a number of features that can be regarded as diagnostic of the family (Trewavas 1977, Chao 1978), including large and complex swimbladder and associated well-developed drumming muscles, enlarged lateral-line canals on the head and pores on the snout and lower jaws and extension of the lateral line to the tip of the caudal fin. However, these features are relatively useless from a palaeontological perspective (see Bannikov et al. 2018). Sasaki (1989) recognized several features that are potentially observable in fossil 
articulated skeletal remains (soft dorsal-fin base elongate, typically much longer than anal-fin base; two anal-fin spines; dorsal- and anal-fin pterygiophores bisegmental; frontals cavernous; palatine expanding ventrally; symplectic dorsally flattened, interdigitating medially with the metapterygoid; metapterygoid and quadrate interdigitating medially; supramaxillae absent; palatine toothless; a single branchiostegal articulating with the posterior ceratohyal), some of which have been also observed in the fossils described herein, thereby supporting their placement within the family Sciaenidae. In particular, as documented above, the two fossil fishes from the Pannonian of the Vienna Basin show frontals cavernous, supramaxilla absent, a long-based soft dorsal fin, and two anal-fin spines. The surprisingly reduced complement of anal-fin rays (only four elements) seems to be unique for these fossils although the posterior incompleteness of the fin cannot be ruled out. The otoliths preserved in situ unequivocally confirm the familial placement. The usually large saccular otoliths of the Sciaenidae are remarkably distinctive from a taxonomic point of view, being relatively elongated with index $\mathrm{OL} / \mathrm{OH}>1$ (usually longer as higher), characteristic sulcus with shorter, wider and shallower ostium and longer, narrower and posteroventrally bent cauda. Both the sides of the sagitta are usually vaulted, the outer one often higher with irregularly bumps and the postcentral umbo. Sciaenid otoliths show a high degree of morphological diversity, as well as a remarkable ontogenetic allometry (e.g. Schwarzhans 1993, Nolf 2013). Ontogenetic series of otoliths have been documented for Umbrina subcirrhosa and Trewasciaena kokeni (e.g. Schwarzhans 1993, Nolf 2013).

Unfortunately, juvenile otoliths of sciaenids are often characterized by a few taxonomically relevant features (e.g. Bannikov et al. 2018). The sagittae in situ described herein clearly pertain to juvenile or subadult individuals.

As discussed above, the family Sciaenidae consists of 67 extant genera (Nelson et al. 2016), plus a number of extinct genera, including some solely based on otoliths (see Schwarzhans 1993, Bannikov et al. 2018). The otoliths preserved in situ allowed us to define the generic and specific placement of the examined specimens, which are therefore referred to Trewasciaena $\mathrm{cf}$. kokeni. This species has been assigned to a variety of genera, including Otolithus (Sciaenidarum), Sciaena, Umbrina, "genus aff. Umbrina" and, more recently to Trewasciaena, an otolith based genus (see Schwarzhans 1993, Bannikov et al. 2018). The two Pannonian fossils reported herein document the earliest skeletal evidence for this genus in the fossil record. Therefore, despite their inadequate preservation, these specimens can provide some information about the potential affinities of this extinct genus. According to Bannikov et al. (2018), the genus Trewasciaena ranges from the early Miocene to the Pleistocene being restricted to fresh and brackish waters in Europe.

Sciaenid otoliths are relatively abundant in the Pannonian of the Central Paratethys (Schubert 1902, Brzobohatý \& Pana 1985). Teleost otoliths, including sciaenids from the Pannonian of the Vienna Basin were summarized

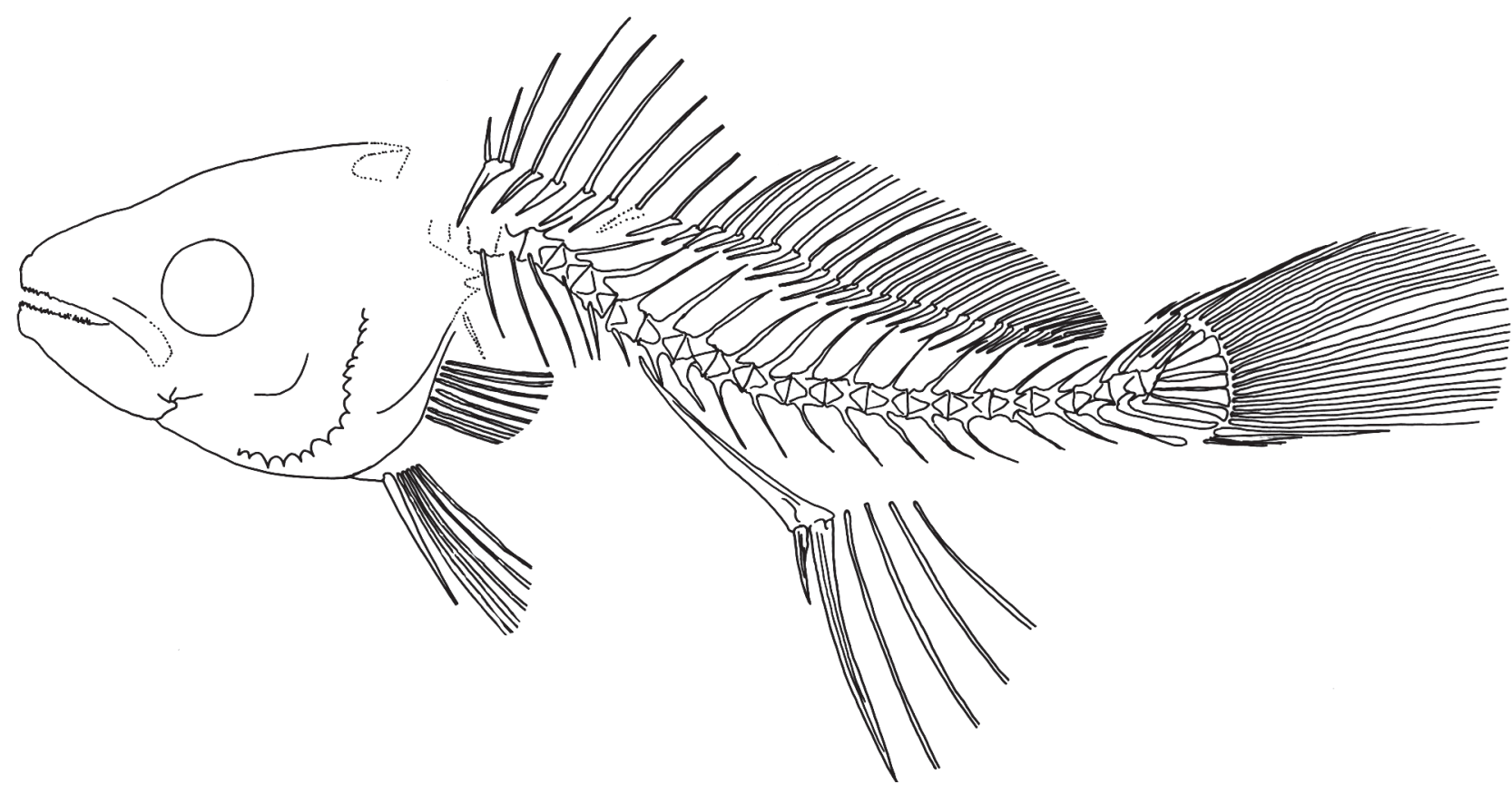

Figure 7. Trewasciaena cf. kokeni (Schubert, 1902). Reconstruction of the skeleton. 
by Brzobohatý \& Pana (1985) and subsequently by Schultz (2013). Nolf (2013) recognized four valid species in this area, including Umbrina subcirrhosa (Schubert, 1902), U. cirrhosoides (Schubert, 1902), "genus aff. Umbrina" kokeni (Schubert, 1902) and Sciaena irregularis (Koken, 1884). A more recent revision of Neogene Paratethyan sciaenids (Bannikov et al. 2018) confirmed the validity of the three first species, suggesting that $S$. irregularis represents an "invalid reference" for the Central Paratethys Badenian. Moreover, Bannikov et al. (2018) reported two other species, Chaoia moguntiniformis (Pana, 1977) and Trewasciaena dobrogiaca (Pana, 1977), both typical of the Eastern Paratethys, of which the last one invaded the Central Paratethys area toward the end of the Pannonian. Otoliths of T. kokeni differ from T. suzini Bratishko, Schwarzhans \& Reichenbacher, 2015 in Bratishko et al. (2015) from the Konkian in being less elongate and having a clearly higher ostium (see Bannikov et al. 2018).

The stratigraphic distribution of Umbrina subcirrhosa is relatively wide, ranging from the Karpatian (uppermost Lower Miocene) to the Pannonian (e.g. Bannikov et al. 2018). A similar range characterizes $U$. cirrhosoides, which occurred from the basal part of the Badenian to the Middle Pontian (Portaferrian in the Dazian Basin; e.g. Bannikov et al. 2018). Trewasciaena kokeni represents a relatively common taxon occuring in the Central Paratethys during most of the Pannonian in Austria (e.g. Leobersdorf Pannonian "B-D"; Mataschen - Pannonian "B"; Brunn a. G. and Vösendorf - Pannonian "E"; Götzendorf Pannonian "F") and Hungary (Tihany, Fonyod - Pannonian "H"; e.g. Schultz 2013). Data from shallow water sediments of the younger Badenian at Děvínská Nová Ves (Slovakia, formerly "Neudorf", "Neudorf a. d. March" or "Theben Neudorf"; Schubert 1906), or from the lower Badenian at Costeiu de Sus (western Romania, Kostej in Hungarian; Schultz 2013, as Sciaena angulata), are based on non-figured material. The last named taxon was also mentioned from the Sarmatian of the Central Paratethys (Brzobohatý \& Stancu 1974, pl. 1, fig. 5) and today is classified as a "rejected" taxon (Nolf 2013, Bannikov et al. 2018). Trewasciaena kokeni is also reported from the Mediterranean region during the late Messinian Lago-mare event (Bannikov et al. 2018).

The overall morphology of the specimens is in some ways reminiscent of that of the species of the genus Umbrina, especially the body proportions, serrated preopercle and second anal-fin spine considerably long and thick (e.g. Walker \& Radford 1992). The genus Umbrina includes 17 extant species plus several otolith-based extinct species (Trewavas 1964, Gilbert 1966, Sasaki 1989, Walker \& Radford 1992, Schwarzhans 1993, Nolf 2013, Bannikov et al. 2018, Parenti 2020). While Trewasciaena cf. kokeni shows a number of dorsal-fin spines and rays consistent with those of several species of the genus
Umbrina, it shares the possession of a massive, greatly elongate and longitudinally striated second anal-fin spine with the Eastern Pacific species $U$. analis from which it differs in having a different number of dorsal-fin (23 vs. 24 to 26), anal-fin (?four $v s$. six) and pectoral-fin (probably eight $v s$. usually 17$)$ rays, procurrent caudal-fin rays $(4+4$ vs. 8-9+7-8) and caudal vertebrae (14 vs. 15) (see Walker $\&$ Radford 1992).

Trewasciaena cf. kokeni also shows a certain degree of similarity with the extant tropical eastern Atlantic species Pseudotolithus elongatus in having a similar body physiognomy (e.g. body moderately elongate, serrated preopercle) and configuration of the anal fin, with an elongate and thick second spine that is long as the first anal-fin ray. However, these taxa can be easily separated from each other due to the different morphology of the sagittae, as well as a different number of dorsal-fin rays (23 vs. 29 to 34; Chao 2016). Finally, Trewasciaena cf. kokeni has a complement of dorsal-fin spines and rays similar to that of Sciaena umbra (11 or 12 spines and 23 to 25 rays; Chao 2016), but differs in overall habitus, morphology of the sagittae, position of mouth, distribution of teeth in the jaws, and anatomy of anal fin.

In conclusion, due to their incompleteness and juvenile nature, the two fossils described herein provide only limited information about the anatomical structure of the genus Trewasciaena (Fig. 7), making problematic the evaluation of its relationships within the Sciaenidae. Additional comparative information based on adult specimens would be necessary to clarify the phylogenetic position of this extinct genus that widely occurred in the fresh- and brackish waters of Europe during the Neogene.

\section{Acknowledgement}

We are grateful to Boris Ekrt (National museum in Prague) for access to collection under his care. Werner Schwarzhans and Bettina Reichenbacher are acknowledged for valuable comments to the earlier version of the manuscript. The research of T.P. was supported by the Czech Academy of the Sciences, Institute of Geology (RVO67985831). The research of G.C. was supported by grants (ex-60\% 2019 and 2020) from the Università degli Studi di Torino.

\section{References}

Bannikov, A.F. 2010. Fossil Acanthopterygian fishes (Teleostei, Acanthopterygii). 244 p. GEOS, Moscow. [in Russian]

Bannikov, A.F., Carnevale, G. \& Landini, W. 2009. A new Early Miocene genus of the family Sciaenidae (Teleostei, Perciformes) from the Eastern Paratethys. Comptes Rendus Palevol 8(6), 535-544. DOI 10.1016/j.crpv.2009.03.001

Bannikov, A.F., Schwarzhans, W. \& Carnevale, G. 2018. 
Neogene Paratethyan croakers (Teleostei, Sciaenidae). Rivista Italiana di Paleontologia e Stratigrafia 124(3), 535-571.

Bosnakoff, M. 2008. Late Miocene (Pannonian) sciaenid fish otoliths from Hungary - Preliminary studies. Hantkeniana 6(6), 219-228.

Bosnakoff, M. 2011. Checklist of the fossil fish otoliths in the Department of Palaeontology and Geology, Hungarian Natural History Museum. Fragmenta Palaeontologica Hungarica 29, 49-68.

Bratishio, A., Schwarzhans, W., Reichenbacher, B., VernyHorova, Y. \& Ćorić, S. 2015. Fish otoliths from the Konkian (Miocene, early Serravallian) of Mangyshlak (Kazakhstan): testimony to an early endemic evolution in the Eastern Paratethys. Paläontologische Zeitschrift 89(4), 839-889. DOI 10.1007/s12542-015-0274-4

Brzobohatý, R. \& Pana, I. 1985. Die Fischfauna des Pannonien, 426-439. In PAPp, A., JÁmBor, A. \& Steininger, F.F. (eds) M6, Pannonien (Slavonien und Serbien). Chronostratigraphie und Neostratotypen, Miozän der Zentralen Paratethys 7. VEDA, Verlag der Slowakischen Akademie der Wissenschaften, Bratislava.

Brzobohatý, R. \& Stancu, J. 1974. Die Fischfauna des Sarmatien s.s., 492-515. In Papp. A., Marinescu, F. \& Seneš, J. (eds) M5, Sarmatien. Die Sarmatische Schichtengruppe und ihr Stratotypus. Chronostratigraphie und Neostratotypen, Miozän der Zentralen Paratethys 4. VEDA, Verlag der Slowakischen Akademie der Wissenschaften, Bratislava.

Carnevale, G., Caputo, D. \& Landini, W. 2006. Late Miocene fish otoliths from the Colombacci Formation (Northern Apennines, Italy): Implications for the Messinian 'Lagomare' event. Geological Journal 41(5), 537-555. DOI 10.1002/gj.1055

Carnevale, G., Dela Pierre, F., Natalicchio, M. \& Landini, W. 2018. Fossil marine fishes and the 'Lago Mare' event: Has the Mediterranean ever transformed into a brackish lake? Newsletters on Stratigraphy 51(1), 57-72. DOI $10.1127 / \operatorname{nos} / 2016 / 0343$

Chaо, N.L. 1978. A basis for classifying Western Atlantic Sciaenidae (Teleostei, Perciformes). NOAA Technical Report Circular 415, 1-64.

Chao, N.L. 1986. Sciaenidae, 865-874. In Whitehead, P.J.P., Bauchot, M.-L., Hureau, J.-C., Nielsen, J. \& Tortonese, E. (eds) Fishes of the North-eastern Atlantic and Mediterranean. UNESCO. Paris. DOI 10.2307/1444931

Chao, N.L. 2002. Sciaenidae, 1583-1653. In CARPEnter, K.E. (ed.) The living marine resources of the Western Central Atlantic. Volume 3: Bony fishes part 2 (Opistognathidae to Molidae), sea turtles and marine mammals. FAO, Rome.

Chao, N.L. 2016. Sciaenidae, 2629-2654. In CARPENTER, K.E. \& Angelis, N.D. (eds) The living resources of the Eastern Central Atlantic. Volume 4: Bony fishes part 2 (Perciformes to Tetradontiformes) and sea turtles. FAO, Rome.

Colombero, S., Alba, D.M., D’Amico, C., Delfino, M., Esu, D., Giuntelli, P., Harzhauser, M., Mazza, P.P.A., Mosca, M., Neubauer, T.A., Pavia, G., Pavia, M., Villa, A. \& CarneVALE, G. 2017. Late Messinian mollusks and vertebrates from Moncucco Torinese, north-western Italy. Paleoecological and paleoclimatological implications. Palaeontologia Electronica 20(1), 1-66. DOI 10.26879/658

Cuvier, G. 1829. Le Règne Animal, distribué d'après son organisation, pour servir de base à l'histoire naturelle des animaux et d'introduction à l'anatomie comparée. Nouvelle Édition, Revue et Augmentée. Tome II. xv + 406 pp. Déterville et Crochard. Paris.

ČTYROKÝ, P. 2000. Nové litostratigrafické jednotky pannonu vídeňské pánve na Moravě. Věstník Českého geologického ústavu 75(2), 159-170.

DolákovÁ, N. \& KovÁČová, M. 2008. Pannonian vegetation from the Northern part of Vienna Basin. Acta Musei nationalis Pragae, Series B 64(2-4), 163-171.

GiLbert, C.R. 1966. Western Atlantic sciaenid fishes of the genus Umbrina. Bulletin of Marine Science 16(2), 230-258.

Harzhauser, M., Daxner-Höck, G. \& Piller, W.E. 2004. An integrated stratigraphy of the Pannonian (Late Miocene) in the Vienna Basin. Austrian Journal of Earth Sciences 95-96, 6-19.

HoněK, J., Francư, J., Doláková, N., KrásnÝ, J., Mikuláš, R., Pešek, J., Pipík, R., SÝkorová, I. \& Tomanová-Petrová, P. 2010. Vídeňská pánev, 334-375. In PEŠEK, J. ET AL. (eds) Terciérní pánve a ložiska hnědého uhli České republiky. Česká geologická služba, Praha.

JiŘíčEK, R. 1985. Anteil in der Tschechoslowakei, 63-65. In PApp, A., JÁmbor, A. \& Steininger, F.F. (eds) M6, Pannonien (Slavonien und Serbien). Chronostratigraphie und Neostratotypen, Miozän der Zentralen Paratethys 7. VEDA, Verlag der Slowakischen Akademie der Wissenschaften, Bratislava.

Johnson, G.D. 1993. Percomorph phylogeny - progress and problems. Bulletin of Marine Science 52(1), 3-28.

Knobloch, E. 1969. Tertiäre Floren von Mähren. 201 pp. Moravské museum and Muzejní spolek, Brno.

KoKen, E. 1884. Über Fisch-Otolithen, insbesondere über diejenigen der norddeutschen Oligocän-Ablagerungen. Zeitschrift der deutschen geologischen Gesellschaft 36, 500-565.

Kováč, M., Sliva, L., Sopková, B., Hlavatá, J. \& Škulová, A. 2008. Serravallian sequence stratigraphy of the northern Vienna Basin: High frequency cycles in the Sarmatian sedimentary record. Geologica Carpathica 59(6), 545-561.

LöRENTHEY, J. 1906. Beiträge zur Fauna und stratigraphischen Lage der pannonischen Schichten in der Umgebung des Balatonsees. Resultate der wissenschaftlichen Erforschung des Balatonsees 1(1), 1-216.

Nelson, J.S., Grande, T.C. \& Wilson, M.V.H. 2016. Fishes of the World, Fifth Edition. 752 pp. John Wiley \& Sons, inc. Hoboken. DOI 10.1002/9781119174844

Nolf, D. 2013. The Diversity of Fish Otoliths Past and Present. 222 pp. Royal Belgian Institute of Natural Sciences, Brussels.

Otero, O., Béarez, P. \& Argyriou, T. 2013. First identification of the genus Argyrosomus (Teleostei, Sciaenidae) in Neogene African outcrops. Geodiversitas 35(1), 49-65. DOI $10.5252 / \mathrm{g} 2013 \mathrm{n} 1 \mathrm{a} 4$

PANA, I. 1977. Problems arisen by the appearance of the new otoliths species and their stratigraphical implications, 
examples of the Dacian otoliths from S. Dobrudja. Analele Universitatii Bucuresti, Geologie 26, 105-124.

Papp, A. 1951. Das Pannon des Wiener Beckens. Mitteilungen der Geologischen Gesellschaft in Wien 39-41(1946-1948), 99-193.

PARENTI, P. 2020. An annotated checklist of fishes of the family Sciaenidae. Journal of Animal Diversity 2(1), 1-92. DOI 10.29252/JAD.2020.2.1.1

Presti, P., Johnson, G.D. \& Datovo, A. 2020. Facial and gill musculature of polynemid fishes, with notes on their possible relationships with sciaenids (Percomorphacea: Perciformes). Journal of Morphology 281(6), 662-675. DOI 10.1002/jmor.21134

Ramcharitar, J., Gannon, D. \& Popper, A. 2006. Bioacoustics of fishes of the family Sciaenidae. Transactions of the American Fisheries Society 135(5), 1409-1431.

DOI 10.1577/T05-207.1

SASAKI, K. 1989. Phylogeny of the family Sciaenidae, with notes on its zoogeography (Teleostei, Percifomes). Memoirs of the Faculty of Fisheries Sciences, Hokkaido University 36(1-2), 1-137. DOI 10.1007/BF02905681

Schubert, R.J. 1902. Die Fischotolithen des österr.-ungar. Tertiärs. I. Die Sciaeniden. Jahrbuch der KaiserlichKöniglichen Geologischen Reichsanstalt 51, 301-316.

Schubert, R.J. 1906. Die Fischotolithen des österr.-ungar. Tertiärs. III. Jahrbuch der Kaiserlich-Königlichen Geologischen Reichsanstalt 56, 623-706.
Schultz, O. 2013. Catalogus Fossilium Austriae Band 3. Pisces. 576 pp. Österreichische Akademie der Wissenschaften, Wien. DOI 10.2307/j.ctt1vw0qw3

Schwarzhans, W. 1993. A comparative morphological treatise of recent and fossil otoliths of the family Sciaenidae (Perciformes). Piscium Catalogus: Part Otolithi Piscium 1, $1-245$.

Schwarzhans, W. \& Carnevale, G. 2017. Otoliths in situ from Sarmatian (Middle Miocene) fishes of the Paratethys. Preface: a first attempt to fill the gap between the otolith and skeletal records of teleost fishes. Swiss Journal of Palaeontology 136(1), 1-6. DOI 10.1007/s13358-017-0126-9

Schwarzhans, W., Beckett, H.T., Schein, J.D. \& Friedman, M. 2018. Computed tomography scanning as a tool for linking the skeletal and otolith-based fossil records of teleost fishes. Palaeontology 61(4), 511-541. DOI 10.1111/pala.12349

Trewavas, E. 1962. A basis for classifying the Sciaenid fishes of tropical West Africa. Annals and Magazine of Natural History, Series 13 5(51), 167-176. DOI 10.1080/00222936208651230

Trewavas, E. 1964. The Sciaenid fishes with a single mental barbel. Copeia 1964(1), 107-117. DOI 10.2307/1440838

Trewavas, E. 1977. The sciaenid fishes (croakers or drums) of the Indo-West-Pacific. The Transactions of the Zoological Society of London 33(4), 253-541.

Walker, H.J. JR. \& RADFORD, K.W. 1992. Eastern Pacific species of the genus Umbrina (Pisces: Sciaenidae), with a description of a new species. Fishery Bulletin 90(3), 574-587. 